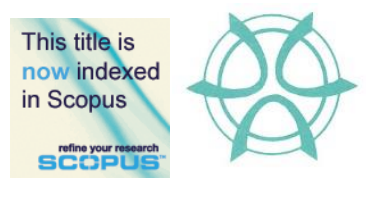

PLANNING MALAYSIA:

Journal of the Malaysian Institute of Planners

VOLUME 17 ISSUE 2 (2019), Page 179 - 190

\title{
QUANTIFYING THE ABOVEGROUND BIOMASS AND CARBON STORAGE OF URBAN TREE SPECIES IN SOKOTO METROPOLIS, NORTH-WESTERN NIGERIA
}

\author{
Dangulla Murtala ${ }^{1}$, Latifah Abd Manaf ${ }^{2}$, Mohammed Firuz Ramli ${ }^{3}$, \\ Mohd Rusli Yacob ${ }^{4}, \&$ Ahmad A. Makmom ${ }^{5}$ \\ ${ }^{1}$ Department of Geography \\ USMANU DANFODIYO UNIVERSITY, SOKOTO, NIGERIA \\ ${ }^{2,3,4}$ Department of Environmental Science \\ UNIVERSITI PUTRA MALAYSIA \\ ${ }^{5}$ Department of Environmental Management \\ UNIVERSITI PUTRA MALAYSIA
}

\begin{abstract}
Increases in human activities, land use/cover changes and urbanisation have led to continuous accumulation of carbon dioxide and other greenhouse gases in the atmosphere, thus threatening the efficiency of natural carbon sinks such as urban trees. This paper assessed the aboveground biomass and carbon stock of trees in Sokoto metropolis, North-Western Nigeria, using an allometric equation. The metropolis was stratified into five broad land use/cover types from which 200 sample plots of $30 \mathrm{~m} \times 30 \mathrm{~m}$ were generated. Data on tree species and diameter at breast height were collected from all trees $\geq 5 \mathrm{~cm}$ in diameter within the plots. A total of 722 trees belonging to 30 species in 17 genera and 14 families were identified. The trees stored 854.73 tonnes of biomass equivalent to 427.37 tonnes of carbon with the highest proportion being stored by Azadirachta indica, Mangifera indica, Adansonia digitata, and Ficus polita. There was a significant difference in tree biomass and carbon stock across the land use/cover types $(\mathrm{F}=$ 4.730, $\mathrm{p}<0.001)$. The Green Area recorded the highest carbon density of $96.5 \mathrm{t}$ $\mathrm{ha}^{-1}$ while Farmland recorded the least carbon density $\left(7.4 \mathrm{t} \mathrm{ha}{ }^{-1}\right)$. Urban areas have diverse tree species that could contribute significantly to reducing global atmospheric carbon. This potential, which varies with the species, number, and size of trees, as well as land cover, can be successfully estimated using allometric equations.
\end{abstract}

Keywords: aboveground biomass; carbon stock; diversity; native species; exotic species 
Dangulla Murtala, Latifah Abd Manaf, Mohammed Firuz Ramli, Mohd Rusli Yacob and Ahmad A. Makmom Quantifying the Aboveground Biomass and Carbon Storage of Urban Tree Species in Sokoto Metropolis, North-Western Nigeria

\section{INTRODUCTION}

Carbon dioxide $\left(\mathrm{CO}_{2}\right)$ contributes approximately $84 \%$ of global radiative forcing (World Meteorological Organization, 2014) and 60\% of observed global warming (Grace, 2004) making it the most important anthropogenic greenhouse gas in the atmosphere. The atmospheric concentration of $\mathrm{CO}_{2}$ rose from about $300 \mathrm{ppm}$ in the pre-industrial 1880s to about $405.58 \mathrm{ppm}$ in 2017 (World Meteorological Organization, 2014). This threatens the efficiency of global natural carbon sinks and accelerates the process of global warming (Canadell et al., 2010). Most of these increases are attributable to human activities such as burning fossil fuels, land use/cover changes (Wang et al., 2014), and urbanisation (Churkina, 2016).

Urban areas are centres of economic and commercial activities, as they accommodate more than half of the global population. These areas require higher amount of fossil fuel for transportation, cooking, heating, cooling, and electricity generation; thus, emitting higher atmospheric carbon (Pataki et al., 2006). According to the United Nations (2018), the rates of urbanisation are higher in Asia and Africa where levels of carbon dioxide emissions are also higher (Clerici, Rubiano, Abd-Elrahman, Posada, \& Escobedo, 2016). It was envisaged that Africa would contribute about $21 \%$ of the global urban population, with Nigeria expected to contribute an estimated 186 million people by 2050 (United Nations, 2018).

Urban trees and forests are increasingly being recognised as important components of biodiversity, hence gaining more relevance for academic, planning, and urban sustainability purposes (Dahlhausen, Biber, Rötzer, Uhl, \& Pretzsch, 2016). Trees enhance the resilience of ecosystems in the face of changes and losses due to pests or diseases (Conway \& Vander Vecht, 2015). In urban areas, trees provide free ecosystem services such as the provision of food, shade and fuel, removal of air pollutants, provision of recreational activities and other physical and mental health (Justin et al., 2016), as well as psychological and spiritual benefits (Peter \& Shackleton, 2017). Urban trees also sequester and store large amounts of carbon as they grow over time (Liu \& Li, 2012). The potential for carbon sequestration and storage of trees depend on their density, composition, growing condition and environmental gradients (Chave et al., 2009; Nowak, Greenfield, Hoehn, \& Lapoint, 2013). Despite its global importance however, carbon sequestration and storage potential of urban trees in Africa and many developing regions have not been adequately assessed and documented (McPherson, Xiao, \& Aguaron, 2013). Most urban carbon studies were conducted in developed countries such as the United States (Liu \& Li, 2012). The results obtained from such studies might therefore not extrapolate successfully to areas with different urbanisation patterns (Davies, Edmondson, Heinemeyer, Leake, \& Gaston, 2011). This justifies the need for region-specific estimates so that relevant information for climate change mitigation and urban sustainability 
purposes could be generated. The aim of this paper is, therefore, to estimate the biomass and carbon stock of trees in Sokoto metropolis, North-Western Nigeria and highlight the contribution of individual tree species in the region to urban carbon balance (Tang, Chen, \& Zhao, 2016), reduction of $\mathrm{CO}_{2}$ emissions in the global carbon cycle, and climate change mitigation.

\section{MATERIALS AND METHOD}

\section{The Study Area}

Sokoto is located on latitudes $13^{\circ} 3^{\prime} 5^{\prime \prime} \mathrm{N}$ and longitudes $5^{\circ} 13^{\prime} 53^{\prime \prime} \mathrm{E}$, and covers an area of about $94 \mathrm{~km}^{2}$ (Figure 1). The city has an estimated population of 554,775 people (National Bureau of Statistics, 2016), and lies in a semi-arid region with typical Koppen's tropical wet and dry (Aw) climate (Belda, Holtanová, Halenka, \& Kalvová, 2014). The mean annual temperature in this zone ranges between $21^{\circ} \mathrm{C}$ and $33^{\circ} \mathrm{C}$ while mean annual rainfall ranges between $508 \mathrm{~mm}$ in the driest part to $1,016 \mathrm{~mm}$ in the wettest part (Sanni, Odekunle, \& Adesina, 2012). Vegetation comprises the Sudano-Sahelian type of short, feathery grasses, and some spiny woody species (Nsangu, 2009). The soils are generally leached and ferruginous consisting of silt and sand with hydromorphic soils found in riverine areas (Swindell, 1986).

\section{Sampling and Data Collection}

This study adopted a stratified sampling approach (Zhang et al., 2016), which ensures better representation by taking into account variation in the size of clusters (Levy \& Lemeshow, 2011), thereby increasing sampling precision (Yang, McBride, Zhou, \& Sun, 2005). A Landsat 8 OLI TIRS image of the metropolis for 2015 was pre-processed and classified (see Liu \& Yang, 2015) with TerrSet geospatial monitoring and modelling system into five broad land use/cover classes. These include the Built-up Area, Farmland, Green Area, Open Space, and Wetland/Water. A stratified sample of 200 points was then generated across the land cover classes using the TerrSet sampling facility (Figure 1). This is considered reasonable (Nowak, Crane, Stevens, \& Hoehn, 2003; Nowak, Walton, Stevens, Crane, \& Hoehn, 2008). 
Dangulla Murtala, Latifah Abd Manaf, Mohammed Firuz Ramli, Mohd Rusli Yacob and Ahmad A. Makmom Quantifying the Aboveground Biomass and Carbon Storage of Urban Tree Species in Sokoto Metropolis, North-Western Nigeria

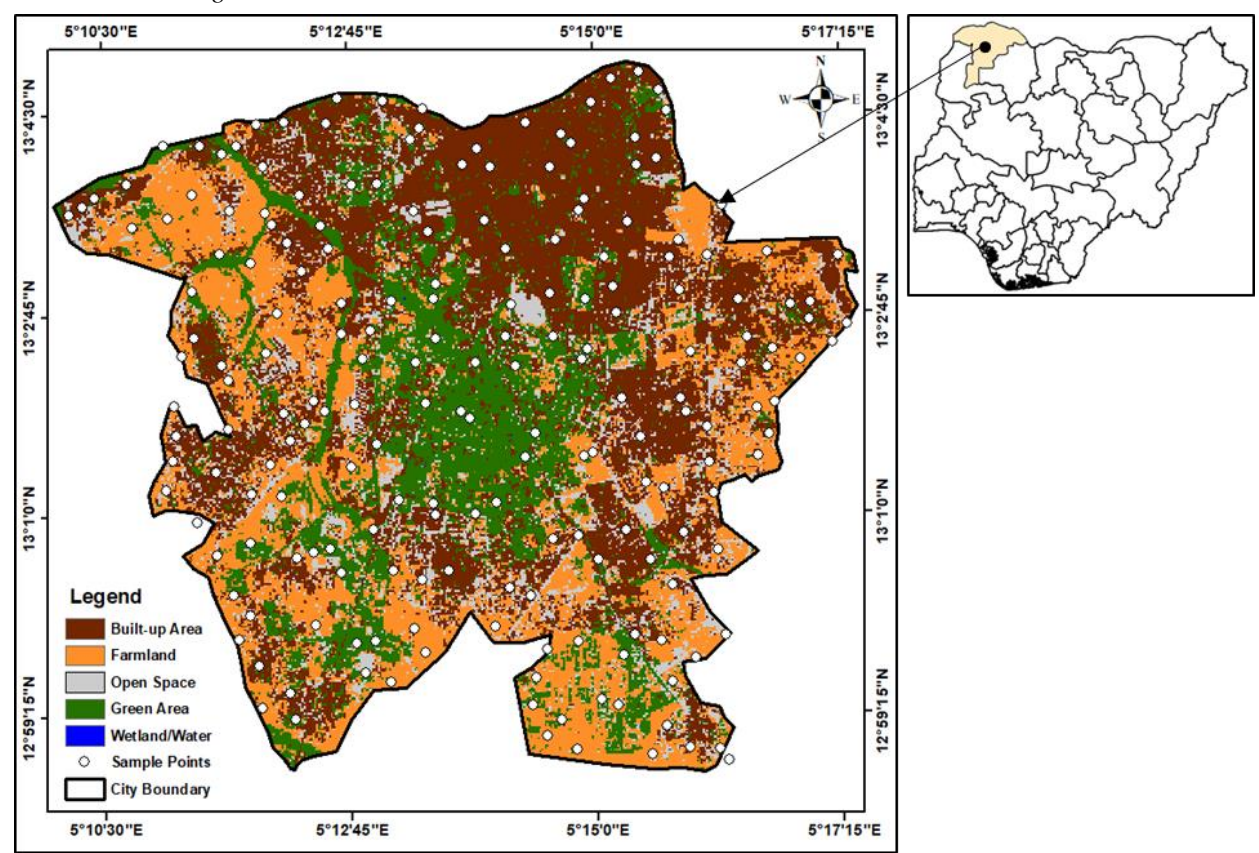

Figure 1 Classified land cover map of Sokoto metropolis and sample points distribution

Tree data were collected from 189 plots, as the remaining 11 plots were not accessible due to privacy issues. We demarcated $30 \mathrm{~m} \times 30 \mathrm{~m}(0.09 \mathrm{ha})$ quadrats at each sample point to coincide with the resolution of the Landsat image used in the classification (Ren et al., 2017). All trees with a diameter $\geq 5 \mathrm{~cm}$ within the quadrats were identified to species level with the aid of a trained botanist. Species provenance (native or exotic) was established with reference to Lely (1925) and Keay, Onochie and Stanfield (1964), while nomenclature followed Hutchinson and Dalziel (1972). Tree diameter at breast height (DBH) was measured $1.3 \mathrm{~m}$ from the ground with a diameter tape, while basal area was derived from Equation (1):

$\mathrm{BA}=\left(d \frac{1}{2}\right)^{2} \pi$

Equation

(1)

where,

$\mathrm{BA}=$ Basal Area

$\mathrm{d}=$ Diameter

$\pi=3.142$ 
PLANNING MALAYSIA

Journal of the Malaysia Institute of Planners (2019)

\section{Data Analysis}

Tree species composition, structural characteristics and density were calculated, while aboveground biomass (AGB) and carbon stock (C) were estimated using an allometric equation. Using allometric equations to estimate AGB is a more popular option (Vashum \& Jayakumar, 2012) than the expensive and timeconsuming, destructive approach (Chave et al., 2014). Many such equations exist in the literature (e.g. Chave et al., 2014; Feldpausch et al., 2011). However, this study adopted the equation provided by Brown, Gillespie and Lugo (1989), which was developed specifically to estimate AGB of trees in dry climates with less than $900 \mathrm{~mm}$ annual rainfall and successfully used in other studies (e.g. O'Donoghue \& Shackleton, 2013; Woldegerima, Yeshitela, \& Lindley, 2017). This is given in Equation (2):

$\mathrm{Y}=\exp \{-1.996+2.32 * \ln (\mathrm{D})\}$

Equation

$(2)$

where,

$\mathrm{Y}=$ biomass per tree $(\mathrm{kg})$

$\exp =\mathrm{e}-($ the base of natural logarithms), raised to the power of $(\ldots)$

$\mathrm{D}=\mathrm{DBH}(\mathrm{cm})$

The equation uses tree $\mathrm{DBH}$ as the predictor variable as this produces the most stable regional AGB estimates (Montagu, Düttmer, Barton, \& Cowie, 2005), while also reducing uncertainties (Liu \& $\mathrm{Li}, 2012$ ). The results were multiplied by a conversion factor of 0.8 (Nowak et al., 2013) to account for the variability in biomass and carbon content between open-grown and high-biomass forest trees, which were used to develop most of the AGB estimation equations. This was then multiplied by 0.5 to obtain carbon stock (Liu \& Li, 2012).

\section{RESULTS AND DISCUSSION}

\section{Tree Species Composition, Biomass and Carbon Stock}

The total number of species recorded, their status, nomenclature and corresponding biomass and carbon stock is given in Table 1. A total of 722 stems belonging to 30 species in 17 genera and 14 families were recorded. The native species accounted for $26.8 \%$ of the stems while exotic species accounted for $73.2 \%$. Species with a higher number of stems include Azadirachta indica (424), Mangifera indica (68), Adansonia digitata (37), Ficus polita (37) and Terminalia catappa (24).

The total tree biomass was estimated at 854.73 tonnes, which is equivalent to 427.37 tonnes of carbon. Species with the highest biomass and carbon stock include Azadirachta indica, Mangifera indica, Adansonia digitata 
Dangulla Murtala, Latifah Abd Manaf, Mohammed Firuz Ramli, Mohd Rusli Yacob and Ahmad A. Makmom Quantifying the Aboveground Biomass and Carbon Storage of Urban Tree Species in Sokoto Metropolis,

North-Western Nigeria

and Ficus polita. These species accounted for $86 \%$ of the total biomass and carbon stock recorded (Table 1).

Table 1 Trees Species composition, provenance, biomass and carbon stock in Sokoto metropolis

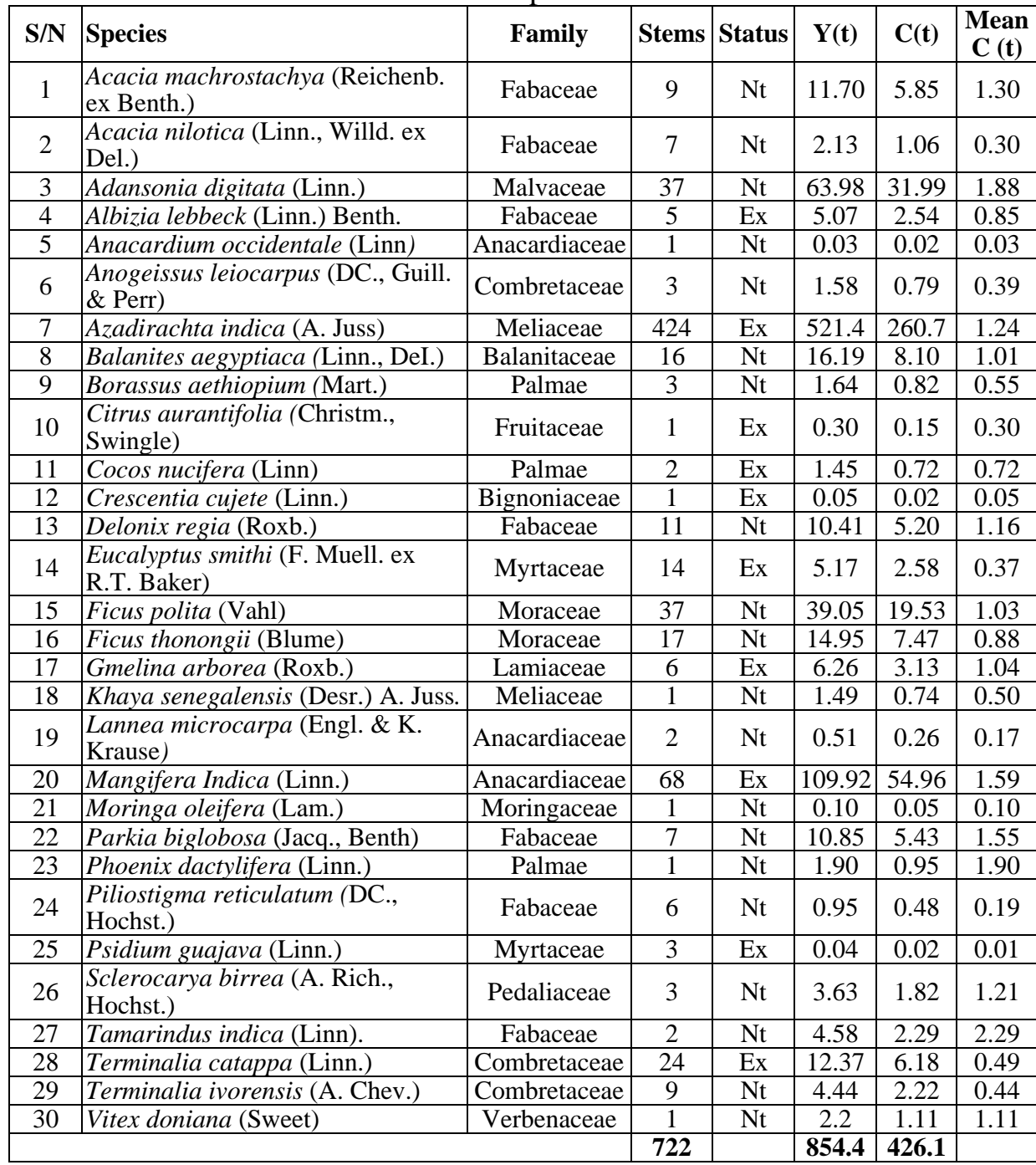

$\mathrm{Nt}=$ Native species; $\mathrm{Ex}=$ Exotic species; $\mathrm{Y}=$ Biomass; $\mathrm{C}=$ Carbon Stock $; \mathrm{t}=$ tonne

\section{Tree Species, Biomass and Carbon Stock Distribution}

Tree species and their individual stems were not evenly distributed across the metropolis. The highest number of stems (447) was recorded in the Built-up Area, followed by the Green Area (134), and Wetland/Water area (52), while the least 
PLANNING MALAYSIA

Journal of the Malaysia Institute of Planners (2019)

number of stems (43) was recorded in the Open Space. Similarly, the highest stem density was obtained in the Green Area $\left(184 \mathrm{ha}^{-1}\right)$ while the lowest stem density $\left(12.9 \mathrm{ha}^{-1}\right)$ was recorded in the Open Space. The density and distribution of biomass and carbon stock also vary significantly between the different land use/cover types. The total biomass and carbon stock were higher in the Built-up and Green areas, while the lowest values were recorded in the Farmland. However, carbon density per hectare was higher in the Green Area (96.5 tonnes $\mathrm{ha}^{-1}$ ) and Wetland/Water area (55.8 tonnes $\mathrm{ha}^{-1}$ ) even though the Built-up Area had higher total biomass and carbon stock (Table 2).

Table 2 Trees species, biomass and carbon stock distribution

\begin{tabular}{cccccccc}
\hline & & \multicolumn{3}{c}{ Total Stems } & & & \\
\cline { 3 - 5 } $\mathrm{S} / \mathrm{N}$ & Land cover & Native & Exotic & Total & $\mathrm{Y}(\mathrm{t})$ & $\mathrm{C}(\mathrm{t})$ & $\mathrm{C}(\mathrm{t} / \mathrm{ha})$ \\
\hline 1 & Built-up Area & 128 & 319 & 447 & 533.1 & 266.54 & 28.8 \\
2 & Farmland & 33 & 13 & 46 & 42.5 & 21.23 & 7.4 \\
3 & Green Area & 5 & 129 & 134 & 139.0 & 69.51 & 96.5 \\
4 & Open Space & 16 & 27 & 43 & 49.8 & 24.92 & 7.5 \\
5 & Wetland/Water & 11 & 41 & 52 & 90.3 & 45.16 & 55.8 \\
& Total & $\mathbf{1 9 3}$ & $\mathbf{5 2 9}$ & $\mathbf{7 2 2}$ & $\mathbf{8 5 4 . 7 3}$ & $\mathbf{4 2 7 . 3 7}$ & \\
\hline
\end{tabular}

$\mathrm{Y}=$ Biomass; $\mathrm{C}=$ Carbon stock

\section{DISCUSSION}

The composition and distribution of trees species in this study (Table 1) shows that Sokoto metropolis is composed of few native and exotic tree species distributed disproportionately across the different land use/cover types. The exotic species however, have higher stem population, thus dominating the landscape. This has been reported in many studies (e.g. Kuruneri-Chitepo \& Shackleton, 2011; Seburanga, Kaplin, Zhang, \& Gatesire, 2014), thereby raising the fear that the exotic species may in the long run, outcompete the native species in many cities due to biotic homogenisation (McKinney, 2006). Hence, much need to be done to improve tree abundance and diversity in the metropolis through afforestation programmes and tree planting campaigns. Such programmes should take account of the many stresses urban tress are exposed to as a result of increasing urban temperatures, restricted rooting space, water deficiencies (Davies et al., 2011) and the ecosystem service potentials of the different tree species.

The total biomass and carbon stock recorded in this study are considerably high when compared to findings from other studies such as Liu and $\mathrm{Li}$ (2012), where mean carbon stock of $33.22 \mathrm{t} \mathrm{ha}^{-1}, 30.25 \mathrm{tha}^{-1}$ and $43.70 \mathrm{tha}^{-1}$ were observed in Shenyang, Hangzhou, and Beijing cities, respectively. However, this is comparatively less than the 552,415 tonnes total carbon reported by Woldegerima et al. (2017) in Addis Ababa. The relatively high tree biomass and carbon stock recorded in this study may be attributable to the number of trees 
Dangulla Murtala, Latifah Abd Manaf, Mohammed Firuz Ramli, Mohd Rusli Yacob and Ahmad A. Makmom Quantifying the Aboveground Biomass and Carbon Storage of Urban Tree Species in Sokoto Metropolis, North-Western Nigeria

with medium to high trunk diameters, which are a characteristic of the Savannah ecosystem where the city is located (Glèlè Kakaï \& Sinsin, 2009). Most of the stems $(73.1 \%)$ have a trunk diameter between $30 \mathrm{~cm}$ and $75 \mathrm{~cm}$. About $2.5 \%$ had a diameter of more than $75 \mathrm{~cm}$ and only $24.4 \%$ of the stems have a trunk diameter of less than $30 \mathrm{~cm}$ (Figure 2).

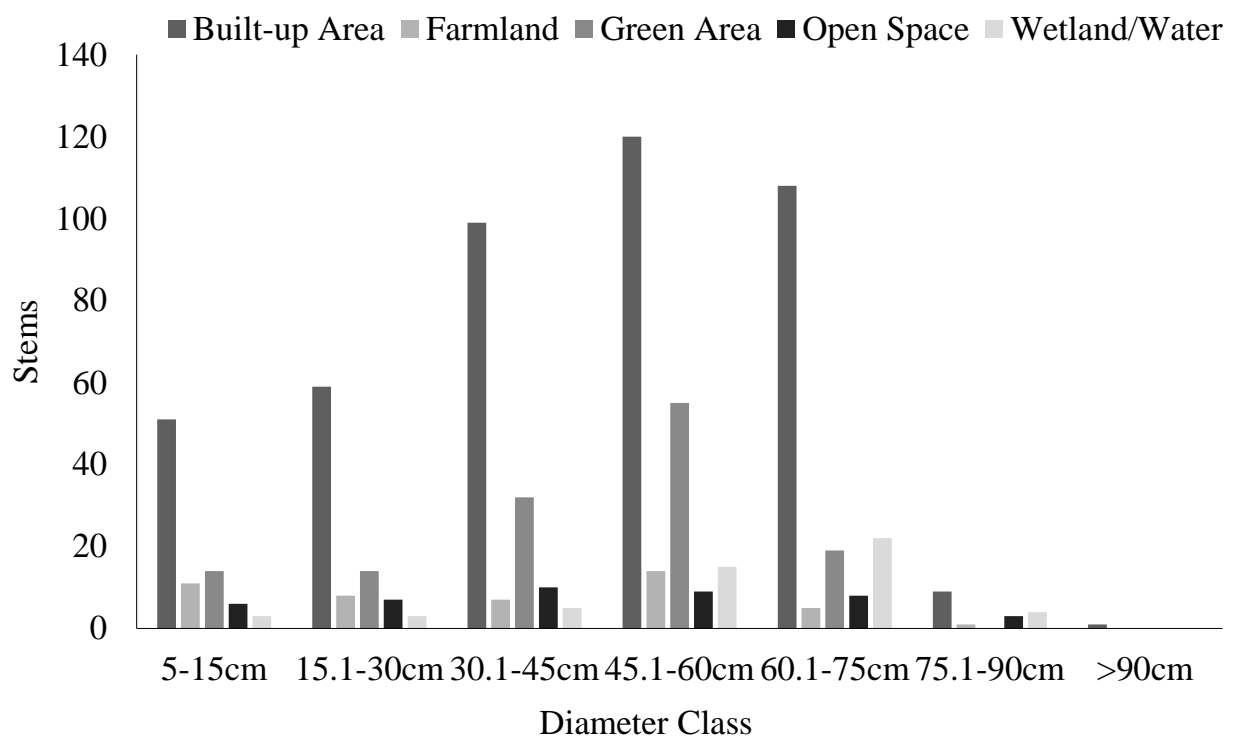

Figure 2 Stem diameter distribution

Although the carbon storage and sequestration potential of urban trees in this part of the world have somehow been neglected, this study shows that urban trees in the region are good carbon sinks. This however, varied with the type of species, diameter and land use/cover type. Species with the highest mean biomass and carbon stock include Tamarindus indica, Phoenix dactylifera, Adansonia digitata, Mangifera Indica and Parkia biglobosa (Table 1). Between the land cover types, the Built-up and Green areas accounted for $80 \%$ of the stems recorded and also accommodate most of the large-diameter trees. Higher total biomass and carbon stock were therefore recorded in these areas (Table 2).

The structural characteristics of tree species recorded in this study varied across the land use/cover types. These to a large extent, determined the biomass and carbon stock of trees in the metropolis. A one-way Analysis of Variance (ANOVA) revealed significant difference in mean stem diameter $(f=5.79, p<$ $0.001)$, mean stem basal area $(f=5.21, p<0.001)$ and consequently, mean stem biomass and carbon stock $(f=4.73, p<0.001)$ across the different land use/cover types. The highest mean stem biomass $(1.73 \mathrm{t} / \mathrm{stem})$ was recorded in the 
Wetland/Water where mean stem diameter was highest and the lowest mean stem biomass $(0.92 \mathrm{t} / \mathrm{stem})$ was recorded in the Farmland where mean stem diameter was correspondingly lower (Table 3 ).

Table 3 Comparison of structural parameters and tree biomass

\begin{tabular}{|c|c|c|c|c|c|c|c|c|}
\hline $\mathrm{S} / \mathrm{N}$ & Parameter & BUA & $\begin{array}{l}\text { Farmlan } \\
\text { d }\end{array}$ & GA & OS & WW & $f$ & $p$ \\
\hline 1 & Total Stems & 477 & 46 & 134 & 43 & 52 & & \\
\hline 2 & $\begin{array}{l}\text { Stem Density } \\
\left(\mathrm{ha}^{-1}\right)\end{array}$ & 48.22 & 15.97 & 186.1 & 12.91 & 64.2 & & \\
\hline 3 & $\begin{array}{l}\text { Mean DBH } \\
(\mathrm{cm}) \pm \mathrm{SD}\end{array}$ & $\begin{array}{l}44.6 \pm \\
20.8 \\
1903.7\end{array}$ & $\begin{array}{l}36.8 \pm \\
23.4\end{array}$ & $\begin{array}{l}43.4 \pm \\
16.95\end{array}$ & $\begin{array}{l}43.3 \pm \\
22.0\end{array}$ & $\begin{array}{l}55.8 \pm \\
18.8\end{array}$ & 5.79 & .001 \\
\hline 4 & $\begin{array}{l}\text { Mean BA } \\
\left(\mathrm{cm}^{2}\right) \pm S D\end{array}$ & $\begin{array}{l} \pm \\
1645.4 \\
3\end{array}$ & $\begin{array}{l}1487.1 \pm \\
1448.29\end{array}$ & $\begin{array}{l}1701.7 \pm \\
1016.16\end{array}$ & $\begin{array}{l}1846.7 \pm \\
1558.16\end{array}$ & $\begin{array}{l}2714.4 \pm \\
1395.61\end{array}$ & 5.21 & .001 \\
\hline 5 & $\begin{array}{l}\text { Mean } \\
\text { Biomass (t) } \\
\pm \text { SD }\end{array}$ & $\begin{array}{l}1.19 \pm \\
1.18\end{array}$ & $\begin{array}{l}0.92 \pm \\
0.96\end{array}$ & $\begin{array}{l}1.03 \pm \\
0.66\end{array}$ & $\begin{array}{l}1.15 \pm \\
1.05\end{array}$ & $\begin{array}{l}1.73 \pm \\
0.95\end{array}$ & 4.73 & .001 \\
\hline
\end{tabular}

\section{CONCLUSION}

Sokoto metropolis is composed of a few tree species which are distributed disproportionately across the land cover classes. Depending on the tree species, tree density and diameter as well as land cover type, these trees store a considerable amount of aboveground biomass and carbon stock and thus, contribute significantly to the regional and global carbon budget. In view of climate change mitigation, Tamarindus indica, Phoenix dactylifera, Adansonia digitata, Mangifera Indica and Parkia biglobosa which have higher mean biomass and carbon stock storage should be adopted as species of choice in the metropolis and widely propagated.

\section{ACKNOWLEDGEMENT}

We acknowledge the support from Universiti Putra Malaysia under Grant GCS15-4002.

\section{REFERENCES}

Belda, M., Holtanová, E., Halenka, T., \& Kalvová, J. (2014). Climate classification revisited: From Köppen to Trewartha. Climate Research, 59(1), 1-13.

Brown, S., Gillespie, A. J. R., \& Lugo, A. E. (1989). Biomass estimation methods for tropical forests with applications to forest inventory data. Forest Science, 35(4), 881-902.

Canadell, J. G., Ciais, P., Dhakal, S., Dolman, H., Friedlingstein, P., Gurney, K. R., ...\& Raupach, M. R. (2010). Interactions of the carbon cycle, human activity, and the climate system: A research portfolio. Current Opinion in Environmental Sustainability, 2(4), 301-311. 
Dangulla Murtala, Latifah Abd Manaf, Mohammed Firuz Ramli, Mohd Rusli Yacob and Ahmad A. Makmom Quantifying the Aboveground Biomass and Carbon Storage of Urban Tree Species in Sokoto Metropolis, North-Western Nigeria

Chave, J., Coomes, D., Jansen, S., Lewis, S. L., Swenson, N. G., \& Zanne, A. E. (2009). Towards a worldwide wood economics spectrum. Ecology Letters, 12(4), 351366.

Chave, J., Réjou-Méchain, M., Búrquez, A., Chidumayo, E., Colgan, M. S., Delitti, W. B. C., ...\& Vieilledent, G. (2014). Improved allometric models to estimate the aboveground biomass of tropical trees. Global Change Biology, 20(10), 31773190.

Churkina, G. (2016). The role of urbanization in the global carbon cycle. Frontiers in Ecology and Evolution, 3, 144.

Clerici, N., Rubiano, K., Abd-Elrahman, A., Posada, H. J., \& Escobedo, F. (2016). Estimating aboveground biomass and carbon stocks in periurban Andean secondary forests using very high resolution imagery. Forests, 7(7), 138.

Conway, T. M., \& Vander Vecht, J. (2015). Growing a diverse urban forest: Species selection decisions by practitioners planting and supplying trees. Landscape and Urban Planning, 138, 1-10.

Dahlhausen, J., Biber, P., Rötzer, T., Uhl, E., \& Pretzsch, H. (2016). Tree species and their space requirements in six urban environments worldwide. Forests, 7(6), 1 19.

Davies, Z. G., Edmondson, J. L., Heinemeyer, A., Leake, J. R., \& Gaston, K. J. (2011). Mapping an urban ecosystem service: Quantifying above-ground carbon storage at a city-wide scale. Journal of Applied Ecology, 48(5), 1125-1134.

Feldpausch, T. R., Banin, L., Phillips, O. L., Baker, T. R., Lewis, S. L., \& Quesada, C. A. (2011). Height-diameter allometry of tropical forest trees. Biogeosciences, 8 , 1081-1106.

Glèlè Kakaï, R., \& Sinsin, B. (2009). Structural description of two Isoberlinia dominated vegetation types in the Wari-Maro Forest Reserve (Benin). South African Journal of Botany, 75(1), 43-51.

Grace, J. (2004). Understanding and managing the global carbon cycle. Journal of Ecology, 92(2), 189-202.

Hutchinson, J., \& Dalziel, J. (1972). Flora of West Tropical Africa. (R. W. J. K. and F. N. Hepper, Ed.) (Revised). London: Crown Agents for Overseas Governments and Administrations.

Justin, M., Östberg, J., Konijnendijk van den Bosch, C., Nielsen, A. B., Hauer, R., Sjöman, H., ...\& Jansson, M. (2016). Urban tree diversity-Taking stock and looking ahead. Urban Forestry and Urban Greening, 15, 1-5.

Keay, R. W. J., Onochie, C. F. A., \& Stanfield, D. P. (1964). Nigerian Trees. Federal Department of Forest Research Ibadan, Nigeria (Vol. 1). Apapa, Lagos: Nigerian National Press Ltd.

Kuruneri-Chitepo, C., \& Shackleton, C. M. (2011). The distribution, abundance and composition of street trees in selected towns of the Eastern Cape, South Africa. Urban Forestry \& Urban Greening, 10(3), 247-254.

Lely, H. V. (1925). The useful trees of Northern Nigeria. London, S.W.1: Crown Agents for the Colonies.

Levy, P. S., \& Lemeshow, S. (2011). Sampling of pPopulations: Methods and applications (Fourth Edition). (n.p.): Wiley.

Liu, C., \& Li, X. (2012). Carbon storage and sequestration by urban forests in Shenyang, 
China. Urban Forestry and Urban Greening, 11(2), 121-128.

Liu, T., \& Yang, X. (2015). Monitoring land changes in an urban area using satellite imagery, GIS and landscape metrics. Applied Geography, 56, 42-54.

McKinney, M. L. (2006). Urbanisation as a major cause of biotic homogenization. Biological Conservation, 127, 247-260.

McPherson, E. G., Xiao, Q., \& Aguaron, E. (2013). A new approach to quantify and map carbon stored, sequestered and emissions avoided by urban forests. Landscape and Urban Planning, 120, 70-84.

Montagu, K. D., Düttmer, K., Barton, C. V. M., \& Cowie, A. L. (2005). Developing general allometric relationships for regional estimates of carbon sequestration An example using Eucalyptus pilularis from seven contrasting sites. Forest Ecology and Management, 204(1), 113-127.

National Bureau of Statistics. (2016). Annual abstract of statistics (Vol. 1). Abuja, Nigeria: Author.

Nowak, D. J., Crane, D. E., Stevens, J. C., \& Hoehn, R. E. (2003). The Urban forest Effects (UFORE) model: Field data collection manual (Vol. 13210). Syracuse, NY: USDA Forest Service, Northeastern Research Station.

Nowak, D. J., Greenfield, E. J., Hoehn, R. E., \& Lapoint, E. (2013). Carbon storage and sequestration by trees in urban and community areas of the United States. Environmental Pollution, 178, 229-236.

Nowak, D. J., Walton, J., Stevens, J. C., Crane, D. E., \& Hoehn, R. E. (2008). Effect of plot and sample size on timing and precision of urban forest assessments methods. Arboriculture and Urban Forestry, 34(6), 386-390.

Nsangu, C. A. (2009). Urban agriculture and physical planning: A case study of Zaria, Nigeria. In M. Redwood (Ed.), Agriculture in urban planning: Generating livelihoods and food security (pp. 217-234). London: Earthscan Publications Ltd.

O'Donoghue, A., \& Shackleton, C. M. (2013). Current and potential carbon stocks of trees in urban parking lots in towns of the Eastern Cape, South Africa. Urban Forestry and Urban Greening, 12(4), 443-449.

Pataki, D. E., Alig, R. J., Fung, A. S., Golubiewski, N. E., Kennedy, C. A., Mcpherson, E. G., ...\& Lankao, P. R. (2006). Urban ecosystems and the North American carbon cycle. Global Change Biology, 12(11), 2092-2102.

Peter, de L., \& Shackleton, C. M. (2017). Aesthetic and spiritual ecosystem services provided by urban sacred sites. Sustainability (Switzerland), 9(9), 1628.

Ren, Z., Du, Y., He, X., Pu, R., Zheng, H., \& Hu, H. (2017). Spatiotemporal pattern of urban forest leaf area index in response to rapid urbanization and urban greening. Journal of Forestry Research, 29(3), 785-796.

Sanni, M., Odekunle, T. O., \& Adesina, F. A. (2012). Spatio-temporal variation of drought severity in the Sudano-Sahelian Region of Nigeria: Implications for policies on water management. In W. L. Filho (Ed.), Climate change and the sustainable use of water resources. Berlin Heidelberg: Springer-Verlag.

Seburanga, J. L., Kaplin, B. A., Zhang, Q.-X., \& Gatesire, T. (2014). Amenity trees and green space structure in urban settlements of Kigali, Rwanda. Urban Forestry \& Urban Greening, 13(1), 84-93.

Swindell, K. (1986). Population and agriculture in the Sokoto-Rima basin of north-west 
Dangulla Murtala, Latifah Abd Manaf, Mohammed Firuz Ramli, Mohd Rusli Yacob and Ahmad A. Makmom Quantifying the Aboveground Biomass and Carbon Storage of Urban Tree Species in Sokoto Metropolis, North-Western Nigeria

Nigeria. A study of political intervention, adaptation and change, 1800-1980. Cahiers d'Etudes Africaines, 101-102, 75-111.

Tang, Y., Chen, A., \& Zhao, S. (2016). Carbon storage and sequestration of urban street trees in Beijing, China. Frontiers in Ecology and Evolution, 4(53), 1-8.

United Nations. (2018). World urbanization prospects: The 2018 revision. Department of Economic and Social Affairs, Population Division, Methodology Working Paper No. ESA/P/WP.252. New York.

Vashum, K. T., \& Jayakumar, S. (2012). Methods to estimate above-ground biomass and carbon stock in natural forests - A review. Journal of Ecosystem \& Ecography, 2(4), 1-7.

Wang, Y., Ji, W., Yu, X., Xu, X., Jiang, D., Wang, Z., \& Zhuang, D. (2014). The impact of urbanization on the annual average temperature of the past 60 years in Beijing. Advances in Meteorology, 014(1), 1-10.

Woldegerima, T., Yeshitela, K., \& Lindley, S. (2017). Ecosystem services assessment of the urban forests of Addis Ababa, Ethiopia. Urban Ecosystems, 20(3), 683-699.

World Meteorological Organization. (2014). The state of greenhouse gases in the atmosphere based on global observations through 2013. Available at https://www.wmo.int/pages/ mediacentre/press

Yang, J., McBride, J., Zhou, J., \& Sun, Z. (2005). The urban forest in Beijing and its role in air pollution reduction. Urban Forestry and Urban Greening, 3(2), 65-78.

Zhang, D., Zheng, H., He, X., Ren, Z., Zhai, C., Yu, X., ... Wang, P. (2016). Effects of forest type and urbanization on species composition and diversity of urban forest in Changchun, Northeast China. Urban Ecosystems, 19(1), 455-473

Received: $12^{\text {th }}$ January 2019. Accepted: $2^{\text {nd }}$ August 2019 